\title{
サーファーズイヤー（外耳道外骨腫）の手術経験
}

\author{
内田育恵植田広海
}

要旨：サーファーズイヤー（外耳道外骨腫）は，長期にわたる慢性的な冷水刺激が外耳道に加わることによ り, 骨部外耳道に生じる骨増殖性隆起である。当教室では, 2009 年 7 月から 2015 年 7 月までの 6 年間に, 8 例 13 耳のサーファーズイヤー手術症例を経験した。手術は全例耳内切開で行い, 合併症はなく良好な結果を 得た。1 症例を提示し手術手技を詳述した。外耳道では過剩な骨削開により, 前壁では顎関節包, 後方では乳 突蜂巣，および顔面神経を損傷するリスクがある。特に顔面神経の走行は，鼓膜輪との位置関係にバリエー ションがあり，外耳道外骨腫の手術合併症予防の観点から，手術手技に関する文献的考察を加えた。 キーワード : 耳内切開, 手術合併症, 顔面神経, 鼓膜輪

\section{Summary Surgical experience of surfer's ear (external auditory canal exostosis):}

Yasue Uchida and Hiromi Ueda. Department of Otorhinolaryngology, Aichi Medical University

Surfer's ear, also known as external auditory canal exostosis, is thought to be a bony growth that forms as a reactive process from repeated cold water exposure. This study is a retrospective review of 13 ears of 8 patients who underwent exostosis removal at Aichi Medical University, Japan between July 2009 and July 2015. We performed the endaural approach for all, and no patients had complications due to the surgery. The detailed surgical technique of a representative case is described. During bone removal of the obstructive external ear canal, the temporomandibular joint, mastoid air cells, and facial nerve are all at risk for injury. Especially, the course of the facial nerve is reported to be quite variable with respect to the annulus, therefore, a literature-based review of the surgical procedure is discussed in order to minimize exostectomy complications.

Key words: endaural approach, complication, facial nerve, annulus

[Received Aug. 3, 2016, Accepted Jan. 5, 2017]

\section{はじめに}

サーファーズイヤー (外耳道外骨腫) は，長期に わたる慢性的な冷水刺激が外耳道に加わることによ り，骨部外耳道に生じる骨増殖性隆起で, サーフィ ンをする者に高頻度にみられることから Seftel が 1977 年にサーファーズイヤーと命名した ${ }^{1)}$ 。外耳道 の骨隆起性病変としては, 真性の骨腫瘍である骨腫 （osteoma）があるが，サーファーズイヤーは外骨 腫（exostosis）と呼ばれて区別されている。骨腫 は孤立性で, 多くは有茎性, 外耳道峡部より外側に

愛知医科大学耳鼻咽喉科

[平成 28 年 8 月 3 日受付, 平成 29 年 1 月 5 日受理]
存在するが, 一方, 外骨腫は外耳道前・後壁に広基 性病変として, しばしば多発し, 両側性で腫瘤の大 部分は外耳道峡部より内側に存在するといわれてい る2)。

サーフィンやマリンスポーツが盛んな地域では, サーファーズイヤーの手術手技を論じた報告がしば しばあり ${ }^{3-6)}$, 欧米からは 100 例以上の外科治療を まとめた論文も報告されている ${ }^{5,6)}$ 。わが国におい

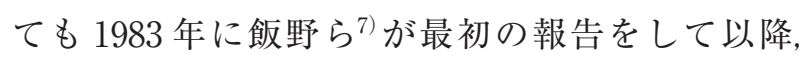
サーファーズイヤーを扱う報告が散見される。

当教室では, 2009 年 7 月から 2015 年 7 月までの 6 年間に, 8 例 13 耳のサーファーズイヤー手術症例 を経験したので, 後方視的に手術手技について検討 し，文献的考察を加えて報告する。 


\section{対象}

2009 年 7 月から 2015 年 7 月までの 6 年間に, 愛 知医科大学耳鼻咽喉科にて手術を行った 8 例 13 耳 である。全例男性で, 手術時年齢は 27 歳から 58 歳 であった。

\section{結果}

表 1 に全症例の概要を示す。受診や手術決意に 至った動機は, 耳閉感や難聴，水が入ると抜けにく くなる症状の自覚や, 感染による耳痛, 耳出血など であった。冷水刺激に関する問診聴取では, 症例 2，3に関しては記録がなく確認できなかったが，5 例はサーファーで, 1 例はカヤック歴が 10 年であっ た。手術は全例全身麻酔で行い, 病変が両耳であっ た 5 例では，両側同日に施行し，皮膚切開は全例耳 内切開で行った。鼓膜穿孔, 顔面神経麻痷, 顎関節 囊損傷などの手術合併症発生は無く, 手術翌日に 行った骨導聴力検査で, 明らかな骨導閾值上昇を認 めた症例は無かった。

手術方法に関しては, 外骨腫の隆起部分の処理 は，基本的に全例同様に行った。すなわち，耳内切 開の皮切線を骨性隆起のほぼ中央に延長し, 病変表 面の皮膚を剥離温存して骨面を露出させ，バーを用 いて隆起を薄くなるまで削り, 骨性隆起裏面の皮虞 を剥離して残った隆起病変を鋭匙またはノミで平坦 化し, 剥離皮膚をもどす, という処理を各隆起病変 に対して行った。
以下に症例 6 について, 手術手技を含めて詳細を報 告し, 他 2 症例の手術前後の外耳道所見を提示する。

\section{症 例 6}

20 歳から 14 年のサーフィン歴があり, 綿棒で耳 を清掃すると耳痛があり，左右どちらに限らず聞こ えにくさも感じるため受診した。図 1 に術前の両側 外耳道鼓膜所見, および聴力検查結果を示す。純音 聴力閾值は, 両側軽度の低音障害型感音難聴を示し ていた。病変は両側性で, 特に右の外耳道外骨腫が 顕著で, 骨性隆起は 2 つり, 鼓膜の半分以上が観 察不能であった。左はほぼ鼓膜が観察できる程度の 小隆起 1 つであった。側頭骨 CT では, 両側頭骨と も蜂巣発育, 含気は良好で中耳病変は認めなかっ た。図 2 に右耳の中耳拡大 CT 所見を示す。骨性隆 起による外耳道の狭窄が確認されたが, 病変は鼓膜 の直前までであると考えられた。手術は全身麻酔下 に, 両耳同日に, 先に左耳, 次に頭位を変更して右 耳を行った。図 3 に右耳の皮切線シェーマと後壁の 大きな骨性隆起の処理について術中所見を示す。骨 部外耳道は, 先に局所麻酔液注入により液性剥離を 行い, メスと三角メスを用いて耳内切開を外耳道後 壁方向に輪状に延ばし, さらに骨性隆起のほぼ中央 に皮虐切開を延長した（図 3.bの(1)から(2)にかけ て)。剥離子，テラメス，ローゼン探針などを用い て, 上皮を剥離して隆起部の骨面を露出させた。 バーを用いて骨性隆起を薄くしながら, 同時に隆起 部の剥離皮膚弁を損傷しないように隆起裏面へ剥離

表 1 全 8 症例の概要

\begin{tabular}{|c|c|c|c|c|c|c|c|}
\hline 症例 & 手術時期 & 性別 & $\begin{array}{l}\text { 手術時 } \\
\text { 年齢 }\end{array}$ & 患側 & 皮切 & $\begin{array}{l}\text { 冷水刺激の } \\
\text { 問診聴取 }\end{array}$ & 症状・受診動機 \\
\hline 1 & 2009 年 11 月 & 男性 & 39 & $\begin{array}{c}\text { 左 } \\
\text { (右もサーファーズ } \\
\text { イヤー手術歴あり) }\end{array}$ & 耳内切開 & $\begin{array}{c}\text { カヤック歴 } \\
10 \text { 年 }\end{array}$ & $\begin{array}{l}\text { 花粉症で近医耳鼻科受診時に外耳 } \\
\text { 道病変指摘。 }\end{array}$ \\
\hline 2 & 2010 年 1 月 & 男性 & 45 & 両 & 耳内切開 & $\begin{array}{l}\text { 聴取記録 } \\
\text { なし }\end{array}$ & 友人に勧められ手術希望で受診。 \\
\hline 3 & 2010 年 9 月 & 男性 & 32 & 両 & 耳内切開 & $\begin{array}{l}\text { 聴取記録 } \\
\text { なし }\end{array}$ & $\begin{array}{l}\text { 右耳痛で近医耳鼻科受診し外耳道 } \\
\text { 病変指摘。 }\end{array}$ \\
\hline 4 & 2010 年 10 月 & 男性 & 27 & 両 & 耳内切開 & $\begin{array}{c}\text { サーフィン歴 } \\
20 \text { 年 }\end{array}$ & 水が入った後から聴力低下。 \\
\hline 5 & 2012 年 10 月 & 男性 & 58 & 右 & 耳内切開 & $\begin{array}{c}\text { サーフィン歴 } \\
40 \text { 年 }\end{array}$ & 右耳閉感。 \\
\hline 6 & 2013 年 11 月 & 男性 & 34 & 両 & 耳内切開 & $\begin{array}{c}\text { サーフィン歴 } \\
14 \text { 年 }\end{array}$ & 綿棒清掃で耳痛。難聴の自覚。 \\
\hline 7 & 2015 年 1 月 & 男性 & 31 & 右 & 耳内切開 & $\begin{array}{l}\text { サーフィン } \\
\text { (期間不明) }\end{array}$ & $\begin{array}{l}\text { サーフィン中に耳から水が抜けな } \\
\text { くなった。 }\end{array}$ \\
\hline 8 & 2015 年 2 月 & 男性 & 52 & 両 & 耳内切開 & $\begin{array}{l}\text { サーフィン } \\
\text { (期間不明) }\end{array}$ & $\begin{array}{l}\text { 近医耳鼻科で外耳道病変指摘。左 } \\
\text { 耳出血を機に手術決意。 }\end{array}$ \\
\hline
\end{tabular}



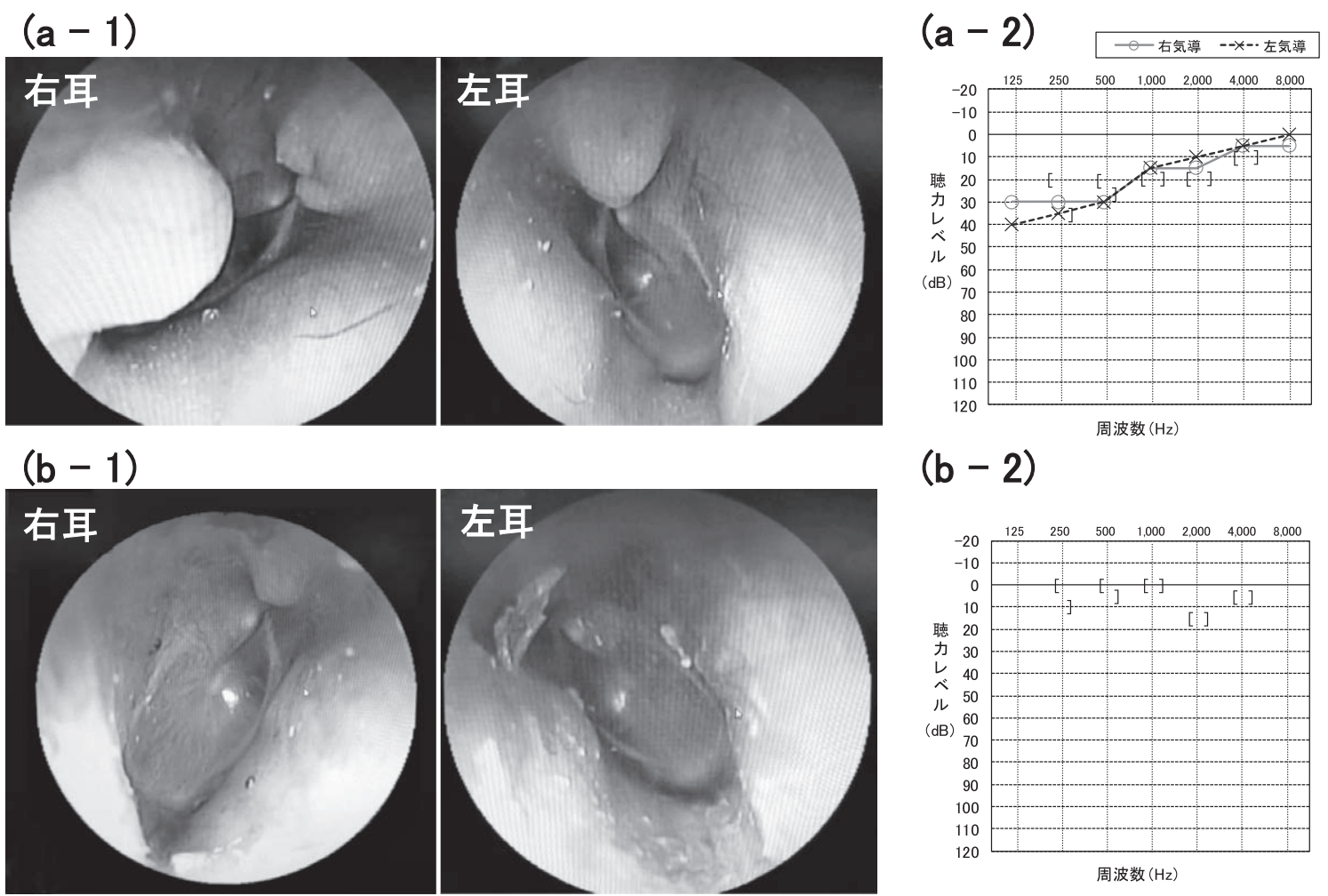

\section{$(b-2)$}

図 1 症例 6 , 手術時年齢 34 歳 男性 術前の外耳道鼓膜写真 $(\mathrm{a}-1)$, 術前の純音聴力検査結果 $(\mathrm{a}-2)$ 術後 3 か月の外耳道鼓膜写真 $\left(b^{-1}\right)$, 術後の骨導聴力検査結果 $(b-2)$
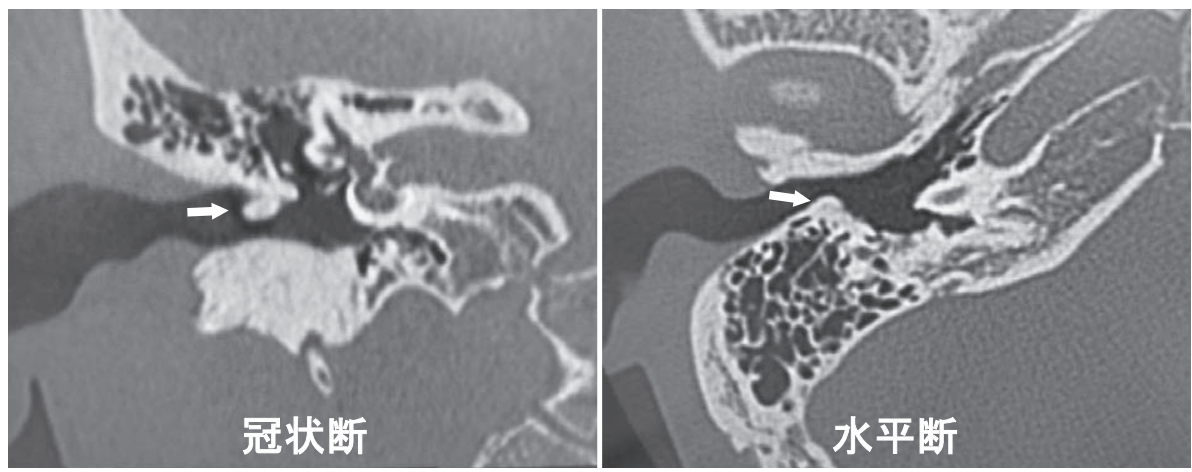

図 2 症例 6 , 手術前の中耳拡大 CT (右耳) 外骨腫の隆起を矢印で示す。

を進め, 薄く残った骨部を $1 \mathrm{~mm}$ ノミで削開し取り 除いた。バーは径 $1.5 \mathrm{~mm}$ カーブファインダイヤモ ンドバー（メドトロニック社製）が有用であった (図 3. c-2 から c-4)。骨表面の凹凸を鋭匙で平坦に 整え, 翻転していた皮膚弁を戻して外耳道形状を確 認した。一つの隆起を処理し終わったら，次の骨隆 起表面に皮膚切開線を延長し（図 3.b の (3)，同様 の手技により外耳道骨面を平坦化し, 最終的に翻転 していた上皮で, できる限り外耳道骨の露出部を被 覆し, ずれないようにフィブリン糊で固定し外耳道 内をパッキングし，耳内切開部を縫合して手術を終
了した。

両耳とも, 手術終了時に全体が観察可能になった 鼓膜に損傷はなく, 術後に行った骨導聴力検査では, 左右とも全周波数領域で正常範囲であった（図 1)。

\section{他 2 症例の手術前後の外耳道鼓膜所見}

図 4 に, 症例 2 と 5 の術前後外耳道鼓膜写真を提 示する。手術手技は同様の方法を用いた。外耳道外 骨腫の存在により, 狭窄部位より奥の耳垢や, 侵入 した水などが出にくくなり感染を起こし, 症例 5 では, 外耳道皮膚が腫脤してほぼ閉塞していた。術前に感 


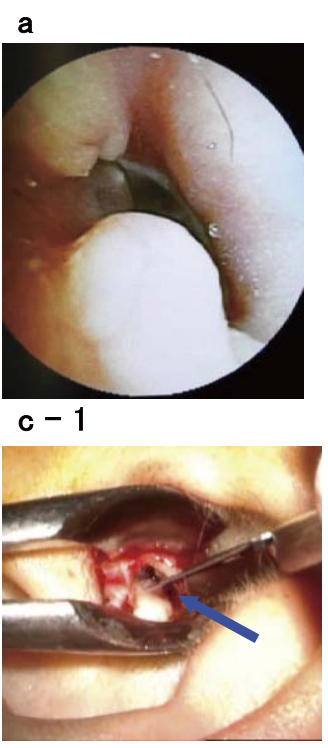

$c-2$

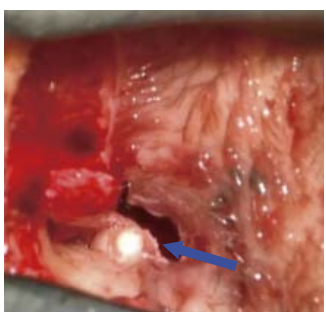

b

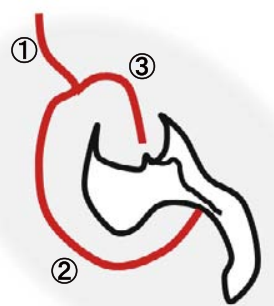

耳内切開を外耳道 後壁に輪状に延ばし 骨性隆起のほぼ中 央に皮膚切開を延 長した。

骨性隆起表面の上 皮を剥離して隆起部 の骨面を露出させた。 $c-3$

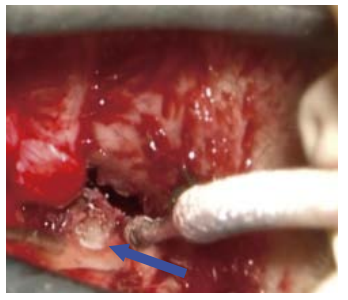

$1.5 \mathrm{~mm}$ カブファイ ンダイヤモンドバー で骨性隆起を薄く 削った。

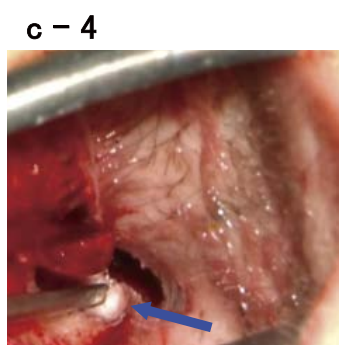

隆起裏面皮膚を剥 離して温存し, 薄く 残った隆起部骨を $1 \mathrm{~mm}$ ノで削開し取 り除いた。

\section{$c-5$}

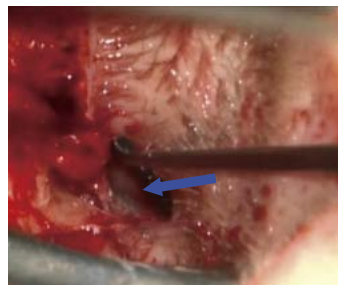

翻転していた皮膚弁 を戻して外耳道形状 を確認。

図 3 症例 6 ,

手術前の右耳外耳道鼓膜写真（a）と皮切線シェーマ（b）後壁の大きな外骨腫処理手順（c-1～5）

症例2

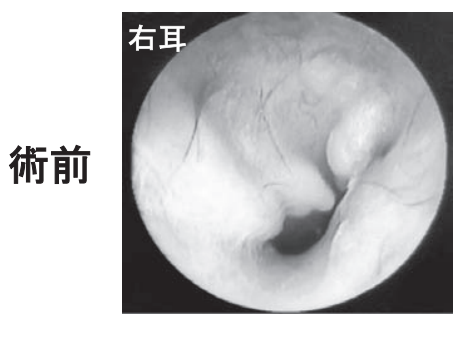

I

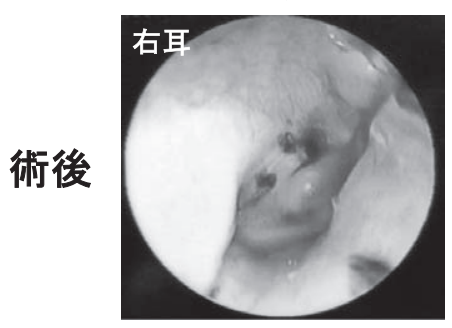

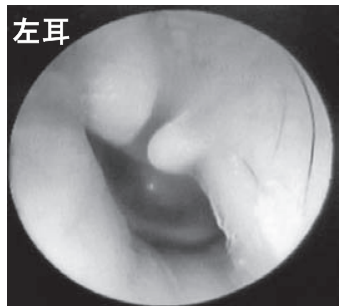

$\downarrow$

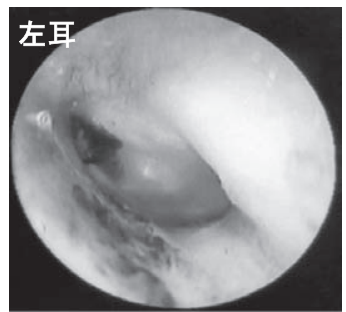

症例5
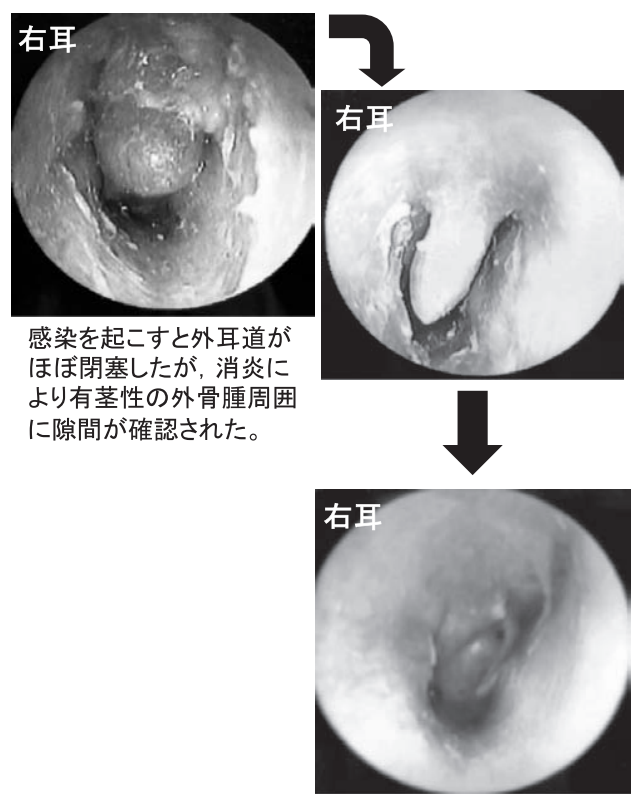

図 4 症例 2 , 症例 5 の術前後外耳道鼓膜写真

染を制御し，炎症を鎮静化させたときの骨性隆起の 形状は，感染時とはかなり異なっており提示した。

\section{考察}

Seftel は，冷たい海で 1 年を通じてサーフィンを
する競技人口の増加とともに, 外耳道骨増殖病変が 高率にみられるようになったとして, サーファーズ イヤーと呼称し1)，その名称が一般的に用いられる ようになった。Alexander らによる207名のサー ファー調査によれば,（1）6 年以上のサーフィン歴, 

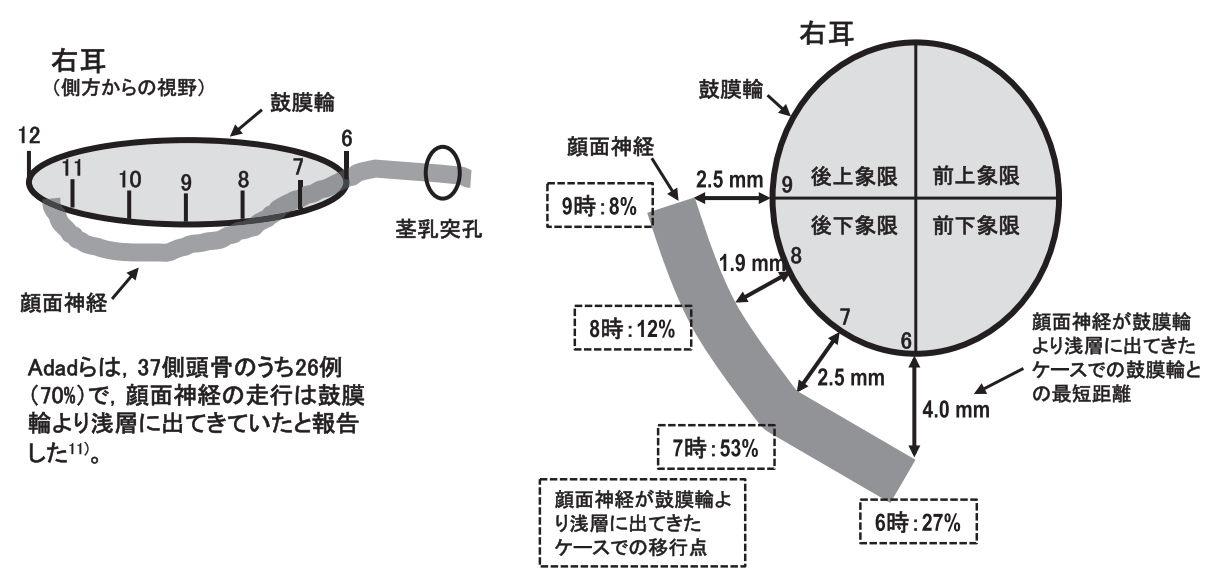

図 5 顔面神経走行と鼓膜輪の位置関係 文献6，11）加引用改变

（2）冬季のサーフィン競技月数，（3）冬季のサー フィン頻度が月 5 回以上，(4) 耳症状を有すること, が統計学的に外耳道外骨腫の存在と有意に関連して いたと報告している8)。海水への曝露だけでなく, 淡水への曝露でも外耳道外骨腫が発生するとされ, 急流で行うカヤック大会参加者 611 名の $79 \%$ に外 耳道外骨腫が認められたとする報告もあった ${ }^{9)}$ 。

術式に関する報告に注目すると, 耳後切開, 耳内 切開, 経外耳道的アプローチのいずれも報告があ る。過去の報告の記述では, 耳後切開は, 術野の十 分な確保, 鼓膜近傍の外耳道処理がしやすい点が利 点である一方, 前壁の処理ができないこと, 顔面神 経麻瘏のリスクが欠点とされ, 耳内切開は, 侵襲が 少ない, 前壁の処理がしやすい点が利点である一 方，鼓膜近傍の処理がしにくく，鼓膜穿孔や，耳小 骨への接触による内耳障害などのリスクが久点とさ れる10)。Sanna らは 65 耳の高度外骨腫例に対する 手術手技を, 図解して説明しており, 最も外耳道狭 窄が軽度な例を除き, 全例耳後切開で行ったとして いる ${ }^{4)}$ 。Sheehy ${ }^{3)}$ は 84 耳の外耳道外骨腫と 16 耳の 外耳道孤発性骨腫の手術経験を報告し, 耳後切開は 経外耳道法と比較し, 骨隆起完全除去に有利で, 術 野確保, 合併症回避, 再発が少ないという点で推奨 している。大田らは, 耳後切開症例の術中所見を示 し, 外耳道皮膚を極力温存し, ドリルやノミを用い て骨部外耳道をすり鉢状に広く削開する様子を提示 している10)。論文内では, “顔面神経垂直部は線維 性鼓膜輪よりも梁部に存在することから, 線維性鼓 膜輪の高さに注意することで, 耳後部切開のリスク といわれる顔面神経麻瘏は必ず回避できると考えら れる。と記されているが, 37 の側頭骨解剖から知

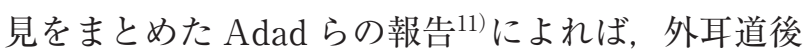
壁の骨削開は，鼓膜輪より浅層であっても必ずしも 安全でないことが指摘されている。骨部外耳道にお

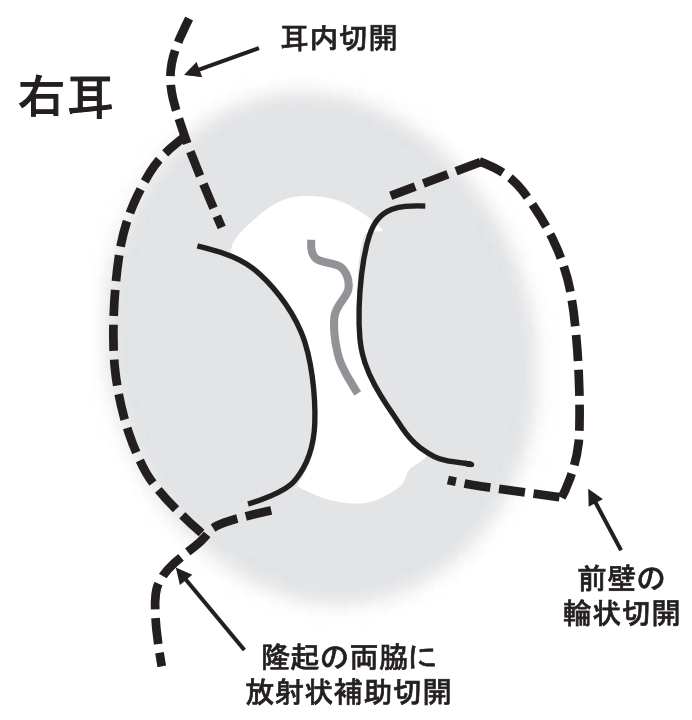

図 6 耳内切開における補助切開線の例 文献 12) から引用改変

ける鼓膜輪と顔面神経走行の位置関係は, 外耳道後 下方のあるポイントで逆転し, 37 側頭骨のうち 26 例 $(70 \%)$ で, 鼓膜輪の高さよりも浅い部位を顔面 神経が走行していた（図 5)。Adad らの報告 ${ }^{11}$ と, Adad らの論文を引用しながら 221 耳の外耳道外骨 腫手術における骨削開手技を紹介した Hetzler の論 文 $^{6)}$ から引用改変した, 外耳道外骨腫手術を行う上 で重要な顔面神経走行に関する知見を，右耳を例に とり図 5 に表した。顔面神経が鼓膜輪より浅層に出 てきたケースの中で, 顔面神経の鼓膜輪からの最短 距離は $1.9 \mathrm{~mm}$ で, 右耳では 9 時から 7 時, 左耳で は 3 時から 5 時の領域であったとされた。外耳道外 骨腫の隆起は, 正常骨組織との境界が明瞭でないこ とも多く, 削開操作中に鼓膜輪の位置を視認できる 耳内切開に利点があると思われる。

われわれは全例耳内切開を採用しており, 特に複 数の隆起病変を有する例では, バーで処理している 
部位と鼓膜輪またはツチ骨短突起との位置関係を随 時確認することにより, 不用意な顔面神経損傷, 鼓 膜穿孔，内耳障害を回避することができると考えて いる。さらに耳内切開法では, 手術中に剥離翻転し た皮膚弁を戻すことにより，容易に外耳道の完成形 状を確認することができる点も，有益であると考え ている。Barrettらも 92 耳の外耳道外骨腫手術を 全例, 耳内切開で行っており, 耳内切開の補助切開 を紹介している12)(図 6)。

外耳道では過剩な骨削開により，前壁では顎関節 包，後方では乳突蜂巣，および顔面神経を損傷する リスクがある。サーファーズイヤーの手術合併症と しては，鼓膜穿孔，ドリリングの強大音や耳小骨接 触に起因する感音難聴，顔面神経麻瘏，顎関節囊損 傷，耳小骨離断，また広範な外耳道皮膚欠損に由来 する肉芽増生, 術後感染や炎症に伴う外耳道再狭

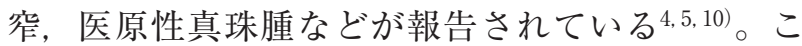
れらの手術合併症を防ぐために, 術前 CTにより, 外骨腫病変と周辺構造の解剖学的関係を十分に把握 しておくことが重要である。われわれは，術前に $0.3 \sim 0.6 \mathrm{~mm}$ スライスの中耳ターゲット CT 軸位断, 冠状断（近年は矢状断も追加）を撮影し，外骨腫病 変深部と耳小骨の接触の有無や, 鼓膜との距離, 側 頭骨内顔面神経，特に乳突部の走行経路を確認して いる。Sanna らは，乳突蜂巣を開放してしまった場 合には，骨粉や軟骨片と筋膜を用いて確実に閉鎖す べきで，閉鎖に失敗すると医原性真珠腫を招くと忠 告している ${ }^{4)}$ 。Vasama は 136 名 182 耳の外耳道外 骨腫手術例から 19 名 (14\%) に手術合併症を認め たとし，手術は経験を積んだ術者が行うべきで，無 症状例への不要な手術は慎むべきであると注意喚起 している5)。術中の工夫として，アルミニウムシー トやシリコンシートをバーや鋭匙で処理する骨隆起 下面にすべり込ませて, 剥離した外耳道皮膚弁の保 護や鼓膜穿孔の予防を行うとする術者もいる ${ }^{4,12)}$

近年は，外耳道外骨腫切除手技に打ける，内視鏡 的経外耳道アプローチの有用性を唱える報告もあ る ${ }^{13)}$ 。斜視鏡により死角のない視野の確保が可能と なることや，助手を含めた “three handed” technique の有効性が紹介されており, 今後，手術合併 症を最小限にする術式考案について，さらなる発展 が期待される。

\section{まとめ}

当教室で 6 年間に 8 例 13 耳のサーファーズイ
ヤー手術症例を経験した。手術は全例耳内切開で行 い, 合併症もなく良好な結果を得た。手術手技の観 点から文献的に考察した。

本論文内容は, 第 26 回日本頭頸部外科学会総会ならび に学術講演会（2016 年 1 月 28-29 日名古屋）での口演内 容に補足を加えたものである。

著者は申告すべき利益相反を有しない。

\section{文献}

1) Seftel DM: Ear canal hyperostosis - Surfer's ear. Arch Otolaryngol $103:$ 58-60, 1977.

2) 小島博己, 沖野容子, 谷口雄一郎, 他: 外耳道扮上 び側頭骨骨腫症例の検討。耳展, 48 : 108-115, 2005.

3) Sheehy JL: Diffuse exostoses and osteomata of the external auditory canal: a report of 100 operations. Otolaryngol Head Neck Surg 90 (3 Pt 1) : 337342, 1982.

4) Sanna M, Russo A, Khrais T, et al: Canalplasty for severe external auditory meatus exostoses. J Laryngol Otol $118: 607-611,2004$.

5) Vasama JP: Surgery for external auditory canal exostoses: a report of 182 operations. ORL J Otorhinolaryngol Relat Spec $65:$ 189-192, 2003.

6) Hetzler DG: Osteotome technique for removal of symptomatic ear canal exostoses. Laryngoscope 117 (1 Pt 2 Suppl 113) : 1-14, 2007.

7）飯野ゆき子，高坂知節，河本和友：Surfer's ear（外耳 道 exostosis）の 1 症例. 耳喉, $55:$ 1009-1012, 1983.

8) Alexander V, Lau A, Beaumont E, et al: The effects of surfing behaviour on the development of external auditory canal exostosis. Eur Arch Otorhinolaryngol $272: 1643-1649,2015$.

9) Moore RD, Schuman TA, Scott TA, et al: Exostoses of the external auditory canal in white-water kayakers. Laryngoscope $120: 582-590,2010$.

10）大田隆之, 松井和夫, 呉 晃一, 他：手術治療した サーファーズ・イア7 耳の検討. 耳鼻臨，107：209$214,2014$.

11) Adad B, Rasgon BM, Ackerson L: Relationship of the facial nerve to the tympanic annulus: a direct anatomic examination. Laryngoscope 109:11891192, 1999.

12) Barrett G, Ronan N, Cowan E, et al: To drill or to chisel? A long-term follow-up study of 92 exostectomy procedures in the UK. Laryngoscope 125 : 453456, 2015

13) Kozin ED, Remenschneider AK, Shah PV, et al: Endoscopic transcanal removal of symptomatic external auditory canal exostoses. Am J Otolaryngol $36: 283-286,2015$. 